\title{
Interstock of 'Valencia' Orange Affects the Flooding Tolerance in 'Verna' Lemon Trees
}

\author{
Vicente Gimeno \\ Centro de Edafología y Biología Aplicada del Segura, CSIC, Campus \\ Universitario de Espinardo, Espinardo, 30100, Murcia, Spain
}

James P. Syvertsen

University of Florida, IFAS, Citrus Research and Education Center, 700

Experiment Station Road, Lake Alfred, FL 33850

Inma Simon

EPSO (Univ. Miguel Hernández), Ctra. Beniel km 3,2 03312 Orihuela

(Alicante), Spain

\author{
Vicente Martinez \\ Centro de Edafología y Biología Aplicada del Segura, CSIC, Campus \\ Universitario de Espinardo, Espinardo, 30100, Murcia, Spain
}

Jose M. Camara-Zapata and Manuel Nieves

EPSO (Univ. Miguel Hernández), Ctra. Beniel km 3,2 03312 Orihuela (Alicante), Spain

\section{Francisco Garcia-Sanchez ${ }^{1}$ \\ Centro de Edafología y Biología Aplicada del Segura, CSIC, Campus Universitario de Espinardo, Espinardo, 30100, Murcia, Spain}

Additional index words. abiotic stress, chlorophyll fluorescence, citrus trees, flood, leaf gas exchange, interstock

\begin{abstract}
Previous work on citrus trees has shown that an interstock, grafted between the rootstock and scion combination, not only can improve tree growth, longevity, fruit production, and quality, but also can increase salinity tolerance. This research was designed to evaluate flooding responses of 2-year-old 'Verna' lemon trees [Citrus limon (L.) Burm.; VL] either grafted on 'Sour' orange ( $C$. aurantium L.; SO) rootstock without an interstock (VL/SO) or interstocked with 'Valencia' orange (C. sinensis Osbeck;VL/V/SO) or with 'Castellano' orange ( $C$. sinensis Osbeck; VL/C/SO). Well-watered and fertilized trees were grown under greenhouse conditions and half were flooded for 9 days. At the end of the flooded period, leaf water relations, leaf gas exchange, chlorophyll fluorescence parameters, mineral nutrition, organic solutes, and carbohydrate concentrations were measured. Leaf water potential $\left(\Psi_{\mathrm{w}}\right)$, relative water content $(\mathrm{RWC})$, net $\mathrm{CO}_{2}$ assimilation rate $\left(\mathrm{A}_{\mathrm{CO} 2}\right)$, and stomatal conductance $\left(g_{\mathrm{S}}\right)$ were decreased by flooding in all the trees but the greatest decreases occurred in $\mathrm{VL} / \mathrm{V} / \mathrm{SO}$. The $\mathrm{C}_{\mathrm{i}} / \mathrm{C}_{\mathrm{a}}$ (leaf internal $\mathrm{CO}_{2}$ to ambient $\mathrm{CO}_{2}$ ratio), $F_{v} / F_{o}$ (potential activity of PSII) and $F_{v} / F_{m}$ (maximum quantum efficiency) ratios were similar in flooded and non-flooded VL/SO and VL/C/SO trees but were decreased in VL/V/SO trees by flooding. Regardless of interstock, flooding increased root calcium (Ca), iron $(\mathrm{Fe})$, copper $(\mathrm{Cu})$, and manganese $(\mathrm{Mn})$ concentration but decreased nitrogen $(N)$ and potassium $(K)$ concentration. Based on the leaf water relations, gas exchange, and chlorophyll parameters, 'Verna' lemon trees interstocked with 'Valencia' orange had the least flooding tolerance. Regardless of interstock, the detrimental effect of flooding in 'Verna' lemon trees was the leaf dehydration which decreased $\mathrm{A}_{\mathrm{CO} 2}$ as a result of non-stomatal factors. Lowered $\mathrm{A}_{\mathrm{CO} 2}$ did not decrease the leaf carbohydrate concentration. Flooding decreased root starch in all trees but more so in VL/V/SO trees. Sugars were decreased by flooding in roots of interstocked trees but were increased by flooding in VL/SO roots suggesting that the translocation of carbohydrates from shoots to roots under flooded condition was impaired in interstocked trees.
\end{abstract}

Spain is the second highest lemon fruitproducing country in the world and the greatest exporter. Approximately $80 \%$ of the Spanish lemon production is located in the arid southeast where drought and salinity stress are common. However, very heavy rainfall frequently occurs in spring and fall, is the limiting availability of oxygen to the roots resulting from different chemical and biochemical reactions (Domingo et al., 2002; Kozlowski, 1997). Such changes can cause citrus trees to respond to flooding by reducing leaf water potential and $g_{\mathrm{S}}$ (Islam et al., 2003; Li et al., 2007; Ruíz-Sánchez et al., 1996). When flooding is prolonged, the $\mathrm{A}_{\mathrm{CO} 2}$ can also be reduced ( $\mathrm{Vu}$ and Yelenosky, 1991). A decrease in root hydraulic conductivity could account for decreased water uptake (RuízSánchez et al., 1996), decreased growth, leaf wilting, and chlorosis (Yelenoski et al., 1995). Root growth typically is reduced by flooding more than shoot growth (Kozlowski, 1997).

The timing of the physiological changes that take place under flooding conditions can also depend on plant size and age (Kozlowski, 1997). In potted 2-year-old 'Verna' lemon trees, Ortuño et al. (2007) observed that leaf water relations were drastically affected after $3 \mathrm{~d}$ under flooding conditions but García-Sánchez et al. (2007) reported that leaf water relations were unaffected during a flooding period of $9 \mathrm{~d}$ in 6-month-old seedlings of 'Carrizo' citrange. Interactions among morphological, anatomical, and physiological factors are very important in plants subjected to flooding (Kozlowski, 1997). Factors influencing tolerance to flooding can include reopening of stomata after soil flooding, rapid recovery of leaf water potential (Li et al., 2004), and an independence of $\mathrm{A}_{\mathrm{CO} 2}$ and $g_{\mathrm{S}}$ during flooding (Fernández et al., 1999) enabling the maintenance of high photosynthetic rates during flooding (Nabben et al., 1999). Under flooding conditions, an energy shortage can occur so remobilization of stored carbohydrates can play a vital role in providing energy needed for cell and organ maintenance as well as for stress responses (Greenway and Gibbs, 2003). For example, anoxia-tolerant plants like rice are able to degrade starch under low $\mathrm{O}_{2}$ conditions (Dixon et al., 2006; Magneschi and Perata, 2009).

Increased superoxide dismutase activity and elevated catalase action can also play an important role in keeping the concentration of reactive oxygen species low under flooded conditions (Hossain et al., 2009). Citrus trees are considered to be flooding-sensitive because citrus does not possess many physiological or anatomical adaptations to flooding, but important differences in tolerance among citrus genotypes have been reported (Arbona et al., 2008). The rootstocks 'Cleopatra' mandarin and citrus Macrophylla are floodingsensitive when compared with SO, 'Citrumelo' swingle, and 'Carrizo' citrange (Agusti et al., 2003; Ruíz-Sánchez et al., 1996; Yelenoski et al., 1995). Arbona et al. (2008) tested all of these rootstocks under flooded conditions and observed that the rootstocks considered floodtolerant had higher antioxidant defences than those considered to be flood-sensitive.

Citrus tolerance to the abiotic stresses can depend on several factors including type of rootstock, $\mathrm{N}$ fertilization, soil, and climate conditions (García-Sánchez and Syvertsen, 2009; Gimeno et al., 2009a; Saleh et al., 2008). In addition, an interstock, grafted 
between the rootstock and scion combination, not only can improve tree growth, longevity, fruit production, and quality (GilIzquierdo et al., 2004), but also can increase salinity tolerance (Gimeno et al., 2009b). The mechanisms related to this higher salt tolerance were that the interstock limited the uptake and transport of $\mathrm{Cl}^{-}$to the shoots by decreasing both the shoot-to-root ratio and leaf transpiration. 'Verna' lemon trees on SO rootstock interstocked with 'Valencia' orange or 'Castellano' orange not only had an improvement in salt tolerance, but also showed that the citrus variety used as the interstock determined the level of salt tolerance (Gimeno et al., 2009b). Effects of an interstock in citrus trees under other abiotic stresses have not been studied. The objective of this experiment was to test the hypothesis that flooding tolerance in citrus trees could be improved by interstocks. We explored the physiological, nutritional, and biochemical responses to flooding of 'Verna' lemon trees on SO rootstock relative to trees that were interstocked with two different orange varieties.

\section{Materials and Methods}

Trees and growth condition. Two-yearold 'Verna' lemon trees [Citrus limon (L.) Burm.] grafted on SO (C. aurantium L.) without an interstock (VL/SO) or interstocked with 'Valencia' orange $(C$. sinensis Osbeck; VL/V/SO) or 'Castellano' orange (C. sinensis; $\mathrm{VL} / \mathrm{C} / \mathrm{SO}$ ) were compared in this experiment. Trees were grown in $25-\mathrm{L}$ pots filled with native clay-loam soil in a greenhouse under maximum photosynthetically active radiation (PAR) of 1000 $\mu \mathrm{mol} \cdot \mathrm{m}^{-2} \cdot \mathrm{s}^{-1}$, day/night temperature of $35 /$ $18 \pm 3{ }^{\circ} \mathrm{C}$, a day/night relative humidity of $55 / 75 \% \pm 5 \%$, and a 16 -h photoperiod. The experimental design was a two $\times$ three factorial of two irrigation treatments (nonflooded and flooded) $\times$ three rootstocks (VL/SO, VL/V/SO, VL/C/SO) with six replicate trees in each treatment.

All trees were irrigated using a drip system and a complete nutrient solution of $7.75 \mathrm{~mm}$ $\mathrm{NO}_{3}{ }^{-}, 0.7 \mathrm{mM} \mathrm{H}_{2} \mathrm{PO}_{4}^{-}, 4.05 \mathrm{~mm} \mathrm{~K}{ }^{+}, 2.20$ $\mathrm{mM} \mathrm{Ca}^{2+}, 0.5 \mathrm{~mm} \mathrm{Mg}^{2+}, 0.5 \mathrm{~mm} \mathrm{SO}_{4}{ }^{2-}$, and 0.6 $\mathrm{mm}$ Fe. Trees were watered everyday with the amount sufficient to leach from the bottom of all pots. Half the trees were flooded by submerging each pot into a 120 -L undrained pot filled with tap water. The water level was maintained at $4 \mathrm{~cm}$ above the soil surface for

Received for publication 4 Nov. 2011. Accepted for publication 10 Jan. 2012.

Funding for this research came from the Ministry of Education and Science, Government of Spain (Project Plan National AGL2007-65437-C04-02/AGR; AGL2011-24795).

V. Gimeno was a PhD student supported by the Fundación Seneca (Región de Murcia).

${ }^{1}$ To whom reprint requests should be addressed; e-mail fgs@cebas.csic.es.
9 d. The tap water contained (mM): 8.86 $\mathrm{SO}_{4}^{-2}, 1.16 \mathrm{HCO}_{3}^{-}, 3 \mathrm{Cl}^{-}, 3.5 \mathrm{~K}^{+}, 0.12$ $\mathrm{Ca}^{2+}, 2.22 \mathrm{Mg}^{2+}$, and $4.13 \mathrm{Na}^{+}$. At the end of the experiment, water relations, net gas exchange, chlorophyll, mineral nutrition, proline, quaternarium ammonium compounds, and carbohydrates were determined in leaves and roots.

Water relations. To assess plant water status, $\Psi_{\mathrm{w}}$, osmotic potential $\left(\Psi_{\pi}\right)$, turgor potential $\left(\Psi_{\mathrm{P}}\right)$, and RWC were measured using a single mature leaf in the midstem region of each of the six replicate trees. Pre-dawn (0500-0700 HR) $\Psi_{\mathrm{w}}$ was measured at the end of the experiment (Day 9) using a pressure chamber (Turner, 1988). After $\Psi_{w}$ was measured, leaves were immediately wrapped tightly in aluminum foil, frozen by immersing in liquid $\mathrm{N}$, and subsequently stored in airtight plastic bags at $-18{ }^{\circ} \mathrm{C}$. After thawing, $\Psi_{\pi}$ of the expressed sap was measured at $25 \pm 1{ }^{\circ} \mathrm{C}$ with an osmometer measuring the freezing point (Digital Osmometer; Roebling, Berlin, Germany) and the Van't Hoff equation: $\Psi_{\mathrm{o}}=-\mathrm{nRT}$ (Nobel, 1991). $\Psi_{\mathrm{P}}$ was calculated as the differences between $\Psi_{\mathrm{w}}$ and $\Psi_{\pi}$. Leaf RWC at midday was measured using adjacent leaves, which were immediately weighed to obtain a leaf fresh weight $\left(\mathrm{M}_{\mathrm{f}}\right)$ and placed in a beaker with their petioles submerged in water overnight in the dark so leaves could become fully hydrated. Leaves were reweighed to obtain turgid mass $\left(\mathrm{M}_{\mathrm{t}}\right)$ and dried at $80{ }^{\circ} \mathrm{C}$ for 24 $\mathrm{h}$ to obtain dry mass $\left(\mathrm{M}_{\mathrm{d}}\right)$. RWC was calculated as $\left[\left(M_{f}-M_{d}\right) \cdot\left(M_{t}-M_{d}\right)^{-1}\right] \times$ 100 (Morgan, 1984). Leaf $\psi_{\mathrm{S}}$ at full turgor $\left(\Psi_{\pi}^{100}\right)$ was also measured on one similar leaf per tree after full hydration overnight as described previously. Fully turgid leaves were then frozen in liquid $\mathrm{N}$, and $\Psi_{\pi}^{100}$ was measured as $\Psi_{\pi}$.

Leaf gas exchange and chlorophyll fluorescence. Net assimilation of $\mathrm{CO}_{2}\left(\mathrm{~A}_{\mathrm{CO} 2}\right)$, leaf transpiration $(\mathrm{E}), g_{\mathrm{S}}$, intercellular $\mathrm{CO}_{2}$ concentration $\left(\mathrm{C}_{\mathrm{i}}\right)$, and instantaneous leaf water use efficiency $\left(\mathrm{WUE}=\mathrm{A}_{\mathrm{CO} 2} / \mathrm{E}\right)$ were measured at the end of the experiment using a portable photosynthesis system (Model LCA-4; ADC Bioscientific Ltd., Hoddesdon, U.K.) and a leaf chamber PLC-4N $\left(11.35 \mathrm{~cm}^{2}\right)$ configured in an open system. All gas exchange measurements were made in the morning from 0800 to $1000 \mathrm{HR}$ to avoid high temperatures and low humidity in the afternoon. During all measurements, $P A R$ exceeded $800 \mu \mathrm{mol} \cdot \mathrm{m}^{-2} \cdot \mathrm{s}^{-1}$, which is sufficient to saturate $\mathrm{A}_{\mathrm{CO} 2}$ citrus leaves (Syvertsen, 1984); leaf temperature was $30 \pm 2{ }^{\circ} \mathrm{C}$ and leaf-to-air vapor pressure difference was $2.4 \pm 0.4 \mathrm{kPa}$ within the cuvette.

Chlorophyll fluorescence parameters were also measured at the end of the experiment with a pulse-modulated fluorometer (Model OS1-Fl; Opti-Sciences, Tyngsboro, MA) on the same leaves used for the of gas exchange measurements. Fluorescence measurements were made after 20 min of darkness under light exclusion leaf clips (FL-DC; OptiSciences). The maximum quantum efficiency
$\left(F_{v} / F_{m}\right)$ of photosystem II (PSII) and potential activity of PSII $\left(F_{v} / F_{o}\right)$ were calculated as $F_{v} / F_{m}=\left(F_{m}-F_{0}\right) / F_{m}$ and $F_{v} / F_{o}=\left(F_{m}-\right.$ $\left.F_{0}\right) / F_{0}$, where $F_{m}$ and $F_{0}$ were maximal and minimal fluorescence measured in darkadapted leaves, respectively (Maxwell and Johnson, 2000).

Growth and leaf and root nutrient concentrations. At the end of the experiment, trees were harvested and separated into leaves, stems, and roots. Tissues were briefly rinsed with deionized water, ovendried at $60{ }^{\circ} \mathrm{C}$ for at least $48 \mathrm{~h}$, weighed, and ground through a sieve with a pore size of $0.5 \mathrm{~mm}$. Tissue $\mathrm{N}$ concentration was measured using a Thermo-Finnigan 1112 EA elemental analyzer (Thermo-Finnigan, Milan, Italy). Tissue $\mathrm{K}^{+}, \mathrm{Mg}^{2+}, \mathrm{Ca}^{+2}, \mathrm{P}, \mathrm{Fe}, \mathrm{Cu}, \mathrm{Mn}$, and $\mathrm{Zn}$ concentrations were determined by inductively coupled plasma emission optical spectrometry (Iris Intrepid II, Thermo Electron Corporation, Franklin, TN) after previous acid digestion using $100 \mathrm{mg}$ of plant material and $8 \mathrm{~mL} \mathrm{HNO}_{3}: \mathrm{H}_{2} \mathrm{O}_{2}(5: 3$ by volume) in a microwave (CEM Marse Xpress, Matthews, NC) reaching $200{ }^{\circ} \mathrm{C}$ in $20 \mathrm{~min}$ and holding at this temperature for $2 \mathrm{~h}$.

Proline and quaternary ammonium compounds. At the end of the experiment, proline was extracted from $0.5 \mathrm{~g}$ of fresh leaf and root tissues with sulphosalicilic acid (3\%) and quantified according to the protocol described by Bates et al. (1973). Quaternary ammonium compounds (QAC) were also extracted from fresh tissues with $1 \mathrm{M} \mathrm{H}_{2} \mathrm{SO}_{4}$ and quantified using the method described by Grieve and Grattan (1983). Proline and QAC concentrations were expressed in units of $\mu \mathrm{g} \cdot \mathrm{mg}^{-1}$ dry weight.

Carbohydrate determination. Carbohydrate concentrations in leaf and root tissues were analyzed at the end of the flooding stress period. Carbohydrates were extracted from $0.5 \mathrm{~g}$ of fresh tissue using $80 \%$ ethanol and constantly stirring for $4 \mathrm{~h}$ at $17-24{ }^{\circ} \mathrm{C}$. A sulfuric acid assay with anthrone reagent was used to measure total soluble carbohydrates in solution (Hodge and Hofreiter, 1962). Concentration of reducing sugars was determined according to the Nelson-Somogyi method (Nelson, 1944; Somogyi, 1952). Starch concentrations were determined after centrifugation (at $1000 \mathrm{~g}$ ) and extraction of the pellet with MES solution and gelatinization with heat-stable alpha amylase in a $92-93{ }^{\circ} \mathrm{C}$ water bath for $1 \mathrm{~h}$ (Haissig and Dickson, 1979). Both soluble sugar and starch were quantified using glucose as the standard.

Statistical analysis. Data were subjected to a two-way analysis of variance (SPSS, Chicago, IL) with three rootstocks $\times$ two flooding treatments and six replicate trees or leaves per treatment. When the interaction terms were significant $(P<0.05)$, treatment means were separated using Duncan's multiple range test. When an interaction term was not significant and main factors (rootstock and/or flooding treatments) were significant, Duncan's multiple range test was run to 
separate means of the main factors (Little and Hills, 1978).

\section{Results}

Growth parameters. 'Verna' lemon trees grafted on $\mathrm{VL} / \mathrm{V} / \mathrm{SO}$ had the highest total plant dry weight (Table 1). This was attributable mainly to the greater root and stem dry weight in $\mathrm{VL} / \mathrm{V} / \mathrm{SO}$ than in $\mathrm{VL} / \mathrm{SO}$ and $\mathrm{VL} / \mathrm{C} / \mathrm{SO}$. The flooding treatment did not affect growth but at the end of $9 \mathrm{~d}$ of flooding, wilting leaves were observed with more severe symptoms in flooded VL/V/SO trees.

Water relation parameters. Leaves from non-flooded trees of $\mathrm{VL} / \mathrm{SO}, \mathrm{VL} / \mathrm{V} / \mathrm{SO}$, and $\mathrm{VL} / \mathrm{C} / \mathrm{SO}$ had similar high values of $\Psi_{\mathrm{w}}$ (Fig. 1). At the end of the experimental period, $\Psi_{\mathrm{w}}$ of flood-stressed plants was decreased in all trees but the greatest reduction was in $\mathrm{VL} / \mathrm{V} /$ SO trees, $-3.1 \mathrm{MPa}$ vs. -1.75 and $-1.52 \mathrm{MPa}$ for $\mathrm{VL} / \mathrm{SO}$ and $\mathrm{VL} / \mathrm{C} / \mathrm{SO}$, respectively. Flooding also decreased $\Psi_{\pi}$ the most in VL/ $\mathrm{V} / \mathrm{SO}$ trees. Leaf turgor potential was decreased by flooding but interstock had no effect on $\Psi_{\mathrm{P}}$ Leaf RWC was lower in flooded than non-flooded trees and this reduction was greater in $\mathrm{VL} / \mathrm{V} / \mathrm{SO}$ trees $(32.6 \%)$ than for either VL/C/SO and VL/SO (both 6.8\%; Fig. $2)$. Leaf $\psi_{\mathrm{S}}$ at full turgor $\Psi_{\pi}^{100}$ was unaffected by flooding.

Gas exchange and fluorescence parameters. In the non-flooded treatment, the interstocked trees had a greater leaf WUE than VL/SO trees as a consequence of a higher $\mathrm{A}_{\mathrm{CO} 2}$ (Fig. 3 ) and lower $E_{\text {leaf }}$ (data not shown). Because $g_{\mathrm{S}}$ was calculated from $\mathrm{E}_{\text {leaf }}$, they were closely related $\left(\mathrm{E}_{\text {leaf }}=16.12 g_{\mathrm{S}}+0.4155 r^{2}=\right.$ $0.9 * * *)$. Flooding reduced $\mathrm{A}_{\mathrm{CO} 2}$ and $g_{\mathrm{S}}$ compared with non-flooded plants and this reduction was greater for $\mathrm{VL} / \mathrm{V} / \mathrm{SO}(71 \%$ and $63 \%$ for $\mathrm{A}_{\mathrm{CO} 2}$ and $g_{\mathrm{S}}$, respectively) than for $\mathrm{VL} / \mathrm{C} / \mathrm{SO}(36 \%$ and $29 \%)$ and $\mathrm{VL} / \mathrm{SO}(21 \%$ and $31 \%$ ). Flooding increased $\mathrm{C}_{\mathrm{i}} / \mathrm{C}_{\mathrm{a}}$ in interstocked trees (VL/C/SO was not significant) but not in VL/SO trees and $F_{v} / F_{m}$ and $F_{v} / F_{0}$ were only significantly decreased by flooding in $\mathrm{VL} / \mathrm{V} / \mathrm{SO}$

Leaf and root solutes concentration. Leaf proline was increased $(184 \%)$ and root proline was decreased (92\%) by flooding in VL/ $\mathrm{V} / \mathrm{SO}$ trees but proline was not significantly affected in VL/C/SO and VL/SO trees (Fig. 4). Leaf QAC concentration was increased and QAC was decreased in roots by the flooding treatment regardless of interstock treatment. Flooding increased leaf total soluble sugars in VL/SO (64\%) but decreased total soluble sugars in $\mathrm{VL} / \mathrm{C} / \mathrm{SO}(28 \%$; Table $2)$. Leaf reducing sugar and leaf starch concentrations were increased by flooding in interstocked trees but not in VL/SO. In the roots, total soluble sugars and reducing sugars were decreased by flooding in interstocked trees but both were increased by flooding in VL/SO. Flooding decreased root starch in all trees but more so in VL/V/SO trees.

Ion concentration in leaves and roots. Leaf macronutrients $(\mathrm{Ca}, \mathrm{K}, \mathrm{Mg}, \mathrm{P}$, and $\mathrm{N}$;

Table 1. Dry weight of total plant, leaves, stem, and root of 'Verna' lemon (VL) trees grafted on 'Sour' orange $(\mathrm{SO})$ rootstock without an interstock $(\mathrm{VL} / \mathrm{SO})$ or interstocked with 'Valencia' orange (VL/V/ $\mathrm{SO})$ or with 'Castellano' orange (VL/C/SO), regardless of flooding treatment.

\begin{tabular}{lcccc}
\hline Rootstock & Total plant $(\mathrm{g} \mathrm{dw})$ & Leaves $(\mathrm{g} \mathrm{dw})$ & Stem $(\mathrm{g} \mathrm{dw})$ & Root $(\mathrm{g} \mathrm{dw})$ \\
\hline VL/SO & $185.6^{\mathrm{c}} \pm 11$ & $80.1^{\mathrm{b}} \pm 4$ & $73.9^{\mathrm{c}} \pm 5$ & $31.6^{\mathrm{c}} \pm 3$ \\
VL/V/SO & $379.1^{\mathrm{a}} \pm 15$ & $107.3^{\mathrm{ab}} \pm 9$ & $186.0^{\mathrm{a}} \pm 5$ & $85.8^{\mathrm{a}} \pm 5$ \\
VL/C/SO & $298.4^{\mathrm{b}} \pm 32$ & $119.6^{\mathrm{a}} \pm 11$ & $123.1^{\mathrm{b}} \pm 17$ & $55.7^{\mathrm{b}} \pm 6$ \\
Analysis of variance & $* * *$ & $*$ & $* * *$ & $* * *$ \\
\hline
\end{tabular}

Values are the mean of 12 samples $( \pm \mathrm{SE})$.

$*$ and $* * *$ indicate significant differences at $P<0.05$ and 0.001 , respectively. Means followed by different letters are significantly different $(P<0.05)$ according to Duncan's multiple range tests. $\mathrm{dw}=$ dry weight

Table 3) and micronutrients in leaves $(\mathrm{Cu}, \mathrm{Fe}$, $\mathrm{Mn}$, and $\mathrm{Zn}$; Table 4) were unaffected by the 9-d flooding treatment. However, flooding increased $\mathrm{Ca}$ in the roots and decreased $\mathrm{N}$ and $\mathrm{K}$ regardless of interstock. Root $\mathrm{P}$ concentration was significantly reduced $64.7 \%$ by flooding in VL/V/SO (Table 3 ). In roots, $\mathrm{Cu}, \mathrm{Fe}$, and $\mathrm{Mn}$ were increased by flooding but $\mathrm{Zn}$ was unaffected regardless of interstock (Table 4).

\section{Discussion}

Leaf water relations, gas exchange, and chlorophyll fluorescence. Based on leaf water relations, leaf gas exchange, and chlorophyll fluorescence parameters (Figs. 1 to 3), interstocked 'Verna' lemon trees on SO did not improve the flooding tolerance relative to VL/ $\mathrm{SO}$ trees. In addition, VL/V/SO trees were less flood-tolerant than $\mathrm{VL} / \mathrm{C} / \mathrm{SO}$ trees. Thus, we could not support our original hypothesis about interstocks improving flooding tolerance. Overall, citrus trees lack specific morphological mechanisms to cope with flooding that are found in flood-tolerant plant species (Glenz et al., 2006). Nonetheless, some citrus rootstocks have physiological mechanisms to tolerate flooding more than others such as the ability to scavenge active oxygen species (Arbona et al., 2008) and to regulate stomatal response to prevent leaf dehydration (GarcíaSánchez et al., 2007). In our study, however, 'Verna' lemon trees did not show any adaptive mechanism to cope with flooding stress. Thus, the lower flood tolerance of VL/V/SO was the result of the detrimental effects of flooding rather than any adaptive mechanisms in VL/ $\mathrm{SO}$ and $\mathrm{VL} / \mathrm{C} / \mathrm{SO}$ trees. The presence of the 'Valencia' orange cultivar as an interstock in 'Verna' lemon trees changed biomass distribution as shown in Table 1 , because these trees had the highest stem and root dry weight (186 and $86 \mathrm{~g}$, respectively). The greater root biomass of VL/V/SO probably placed a greater demand on oxygen transfer to the root system during flooding than $\mathrm{VL} / \mathrm{SO}$ and $\mathrm{VL} / \mathrm{C} / \mathrm{SO}$ so $\mathrm{VL} / \mathrm{V} / \mathrm{SO}$ trees could have depleted $\mathrm{O}_{2}$ concentration in the flooded soil more rapidly than the other trees (Kozlowski, 1997).

Flooded 'Verna' lemon trees, regardless of interstocked or non-interstocked trees, had leaf water relation responses similar to other flooding-sensitive species (Striker et al., 2007). Leaf water potential was decreased by flooding as a consequence of decreasing $\Psi_{\mathrm{P}}$. This fact together with the decrease of

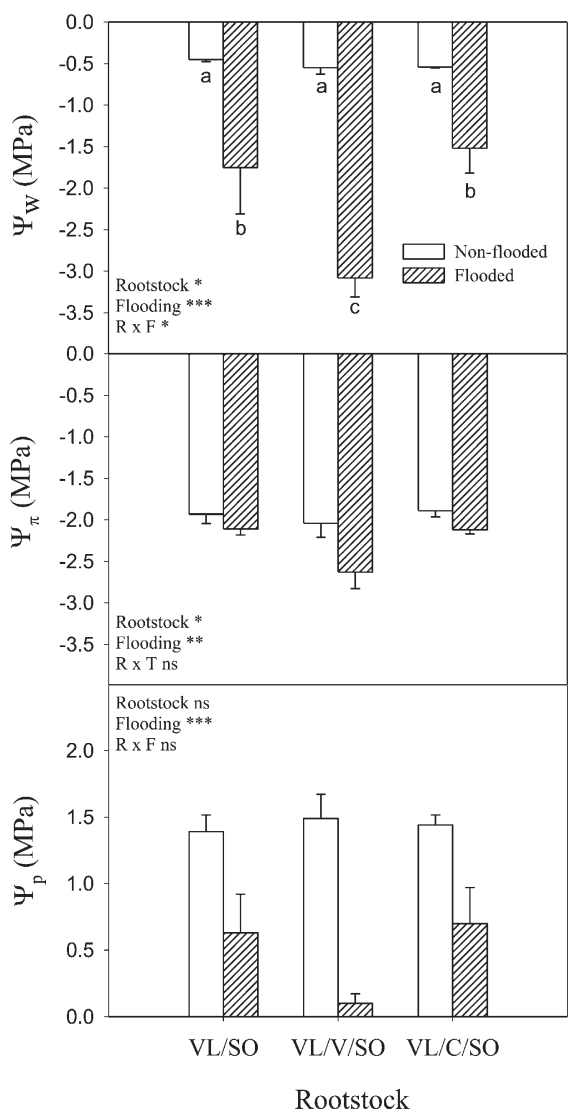

Fig. 1. Pre-dawn potential $\left(\Psi_{\mathrm{w}}\right)$, osmotic potential $\left(\Psi_{\pi}\right)$, and turgor potential $\left(\Psi_{\mathrm{p}}\right)$ in the leaves of flooded and non-flooded 'Verna' lemon (VL) trees grafted on 'Sour' orange (SO) rootstock either without an interstock (VL/SO) or interstocked with 'Valencia' orange (VL/V/SO) or with 'Castellano' orange (VL/C/SO). Bars represent means $\pm \operatorname{SE}(\mathrm{n}=6)$. * $* *$, and $* * *$ indicate significant differences at $P<0.05$, 0.01 , and 0.001 , respectively. Ns indicates nonsignificant differences. When analysis of variance two-way was significant, means of the treatments was separated by Duncan's multiple range test.

the leaf RWC in flooded trees indicated that flooded 'Verna' lemon trees had a reduced ability to take up water. Flooding limits the ability of citrus roots to take up water as a result of a reduction in root hydraulic conductance (Rodríguez-Gamir et al., 2011; Syvertsen et al., 1983).

Although reduced $g_{S}$ is a common response to soil oxygen depletion caused by flooding, the cause of this effect remains 


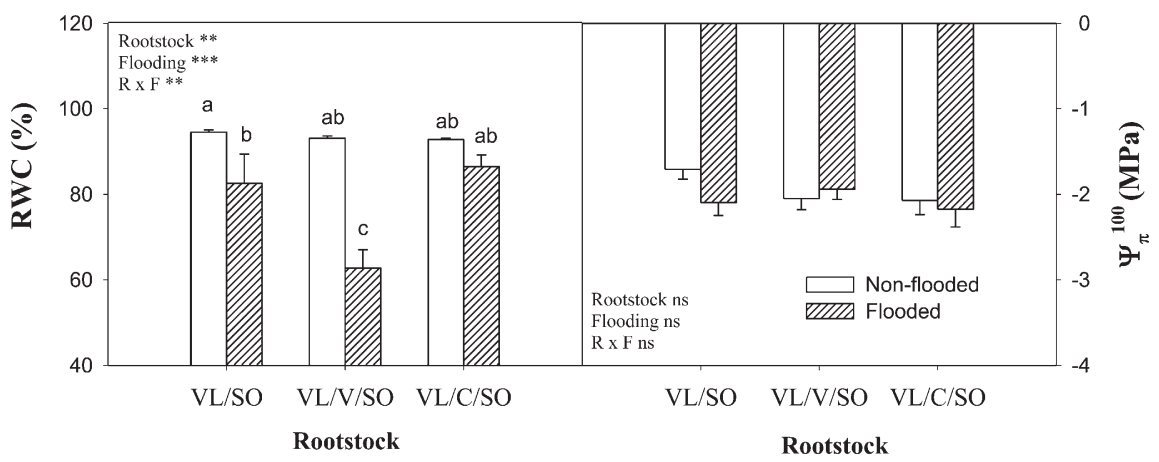

Fig. 2. Leaf osmotic potential $\left(\psi_{\mathrm{S}}\right)$ at full turgor $\left(\Psi_{\pi}^{100}\right)$ and leaf relative water content (RWC) in flooded and non-flooded 'Verna' lemon (VL) trees grafted on 'Sour' orange (SO) rootstock, either without an interstock (VL/SO) or interstocked with 'Valencia' orange (VL/V/SO) or with 'Castellano' orange $(\mathrm{VL} / \mathrm{C} / \mathrm{SO})$. Bars represent means $\pm \mathrm{SE}(\mathrm{n}=6) . *{ }^{* *}$, and $* * *$ indicate significant differences at $P<$ $0.05,0.01$ and 0.001 , respectively. ns indicates nonsignificant differences. When analysis of variance two-way was significant, means of the treatments was separated Duncan's multiple range test.

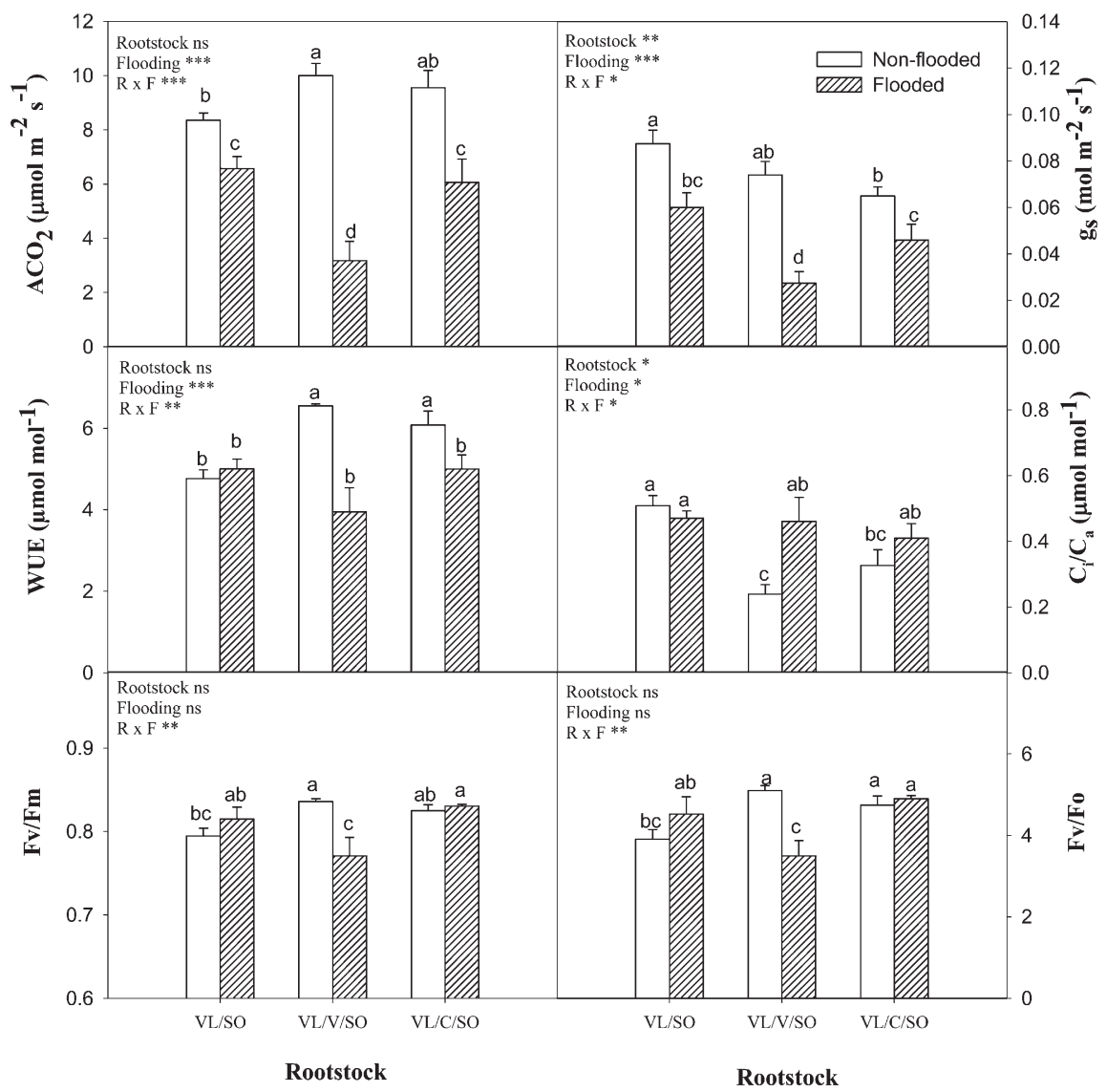

Fig. 3. Net assimilation of $\mathrm{CO}_{2}\left(\mathrm{~A}_{\mathrm{CO} 2}\right)$, stomatal conductance $\left(g_{\mathrm{S}}\right)$, instantaneous leaf water use efficiency $\left(\mathrm{WUE}=\mathrm{A}_{\mathrm{CO} 2} /\right.$ leaf transpiration $), \mathrm{CO}_{2}$ ambient concentration: $\mathrm{CO}_{2}$ substomatal concentration ratio $\left(\mathrm{C}_{\mathrm{i}} / \mathrm{C}_{\mathrm{a}}\right)$, maximum quantum yield $\left(F_{v} / F_{m}\right)$, and potential activity of photosystem II $\left(F_{v} / F_{o}\right)$ in flooded and non-flooded 'Verna' lemon (VL) trees grafted on 'Sour' orange (SO) rootstock, either without an interstock (VL/SO) or interstocked with 'Valencia' orange (VL/V/SO) or with 'Castellano' orange $(\mathrm{VL} / \mathrm{C} / \mathrm{SO})$. Bars represent means $\pm \mathrm{SE}(\mathrm{n}=6) . *, * *$, and $* * *$ indicate significant differences at $P<$ $0.05,0.01$ and 0.001 , respectively. Ns indicates nonsignificant differences. When analysis of variance two-way was significant, means of the treatments was separated according to Duncan's multiple range test.

obscure because hydraulic and/or hormonal mechanisms could also be involved (Else et al., 1996; Horchani et al., 2010; Naumann et al., 2008). In our experiment, the parallel decreases in $\Psi_{\mathrm{w}}, \Psi_{\mathrm{p}}, \mathrm{RWC}$, and $g_{\mathrm{S}}$ point out that the partial stomatal closure was the result
C/SO trees, a non-stomatal factor must have decreased $\mathrm{A}_{\mathrm{CO} 2}$ (Farquhar and Sharkey, 1982). Flexas et al. (2004) also interpreted this type of response in plants under drought as evidence for non-stomatal limiting factors. The decrease in $g_{\mathrm{S}}$ limited $\mathrm{E}_{\text {leaf }}$, which resulted in no change in leaf WUE in response to flooding in $\mathrm{VL} / \mathrm{SO}$ and $\mathrm{VL} / \mathrm{C} / \mathrm{SO}$ trees. In VL/V/SO trees, in which the leaf dehydration by flooding was the greatest, the increase in $\mathrm{C}_{\mathrm{i}} / \mathrm{C}_{\mathrm{a}}$ underscored that nonstomatal factors were dominant in limiting $\mathrm{A}_{\mathrm{CO} 2}$. Measured decreases in $F_{v} / F_{m}$ and $F_{v} /$ $F_{0}$ show that flooding in $\mathrm{VL} / \mathrm{V} / \mathrm{SO}$ trees caused damage to the photochemistry machinery of PSII in leaves. In plants under environmental stress, a decrease in $F_{v} / F_{m}$ usually is the result of a decrease in $F_{\mathrm{m}}$ in combination with an increase in $F_{o}$. In our experiment, $F_{v} / F_{m}$ and $F_{v} / F_{0}$ depletion by flooding in $\mathrm{VL} / \mathrm{V} / \mathrm{SO}$ was the result of a significant increase in $F_{o}$, whereas $F_{m}$ was not altered (data not shown). The decrease $F_{0}$ indicated a dissociation of the light-harvesting pigment system of PSII from the PSII core (Pereira et al., 2000), which has been linked to a short-term rather chronic photoinhibition (Dias and Marenco, 2006).

Nutritional responses to flooding conditions. Macro- and micronutrients in leaves were unaffected by the $9 \mathrm{~d}$ of flooding. In the roots, however, the flooding increased $\mathrm{Fe}, \mathrm{Mn}, \mathrm{Cu}$, and $\mathrm{Ca}$ and decreased $\mathrm{K}, \mathrm{N}$, and $\mathrm{P}$. Because this short-term flooding did not affect plant growth (data not shown), alterations in root mineral nutrition were probably the result of changes in the chemical composition of soil and/or disruption of nutrient uptake. The high concentrations of $\mathrm{Fe}, \mathrm{Cu}$, and $\mathrm{Mn}$ in flooded roots were likely the result of the greater availability of these elements in the soil as a consequence of the fact that these elements are used as electron acceptors through respiration by roots, soil microbes, and soil organisms increasing their mobility in the soil (Waldren et al., 1987). In the case of $\mathrm{N}$, flooding can decrease $\mathrm{N}$ content in the plants as a result of $\mathrm{N}$ leaching from the soil (Unger et al., 2010). Because our short-term experiment was carried out in a closed system, $\mathrm{N}$ depletion in the roots was more likely the result of decreased nitrate uptake by roots from lowered energy-dependent processes from anoxia, which demand a supply of adenosine-5' -triphosphate (Zubay, 1993). Calcium uptake by the roots, however, is passive and does not require energy, but $\mathrm{Ca}$ transport to aerial parts of the plant depends on the transpiration stream (Gilliham et al., 2011), which was reduced by flooding. Flooding has little direct effect on $\mathrm{K}$ availability in the soil, but $\mathrm{K}$ uptake was limited as root $\mathrm{K}$ concentration was reduced by flooding. Anoxia from soil flooding also can lead to the formation of phytotoxic components such as hydrogen sulfide and to the solubilization of aluminum-containing minerals in acid soil that may in turn decrease the uptake of essential nutrients (Rengel, 1992).

Proline and quaternary ammonium compounds. The accumulation of proline 


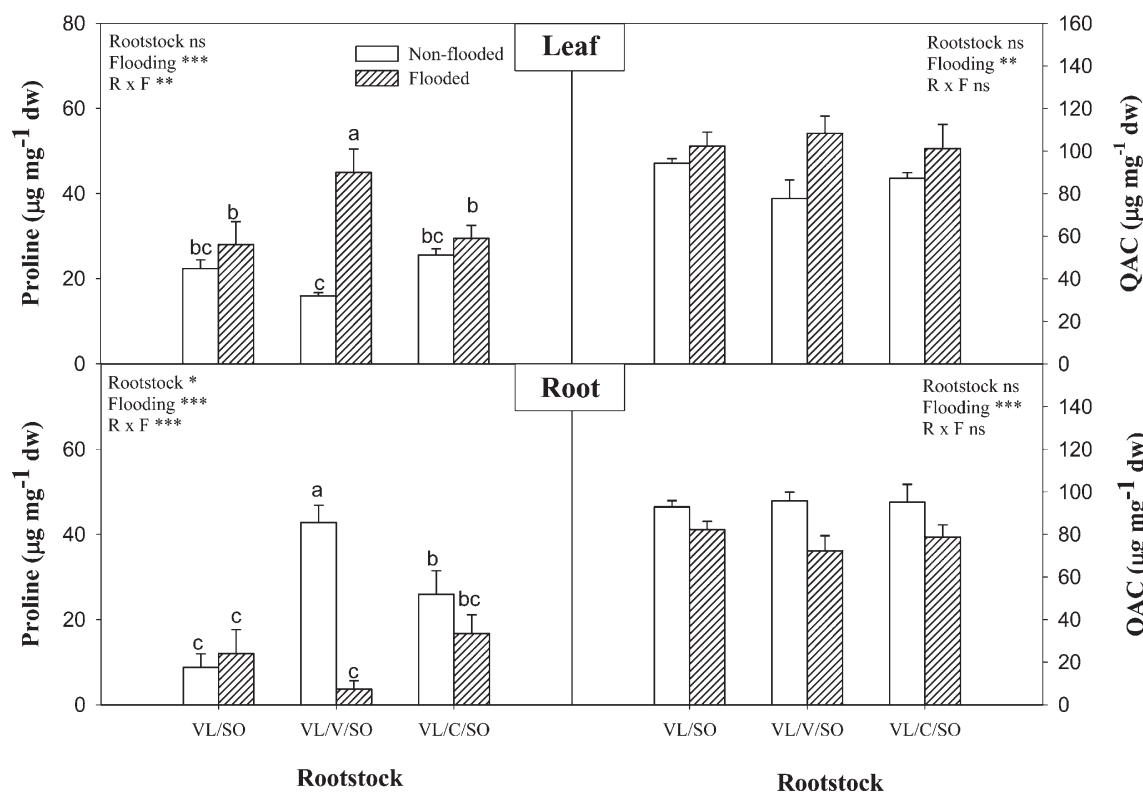

Fig. 4. Concentration of proline and quaternary ammonium compounds (QAC) on leaf and roots of flooded and non-flooded 'Verna' lemon (VL) trees grafted on 'Sour' orange (SO) rootstock, either without an interstock $(\mathrm{VL} / \mathrm{SO})$ or interstocked with 'Valencia' orange $(\mathrm{VL} / \mathrm{V} / \mathrm{SO})$ or with 'Castellano' orange $(\mathrm{VL} / \mathrm{C} / \mathrm{SO})$. Bars represent means $\pm \mathrm{SE}(\mathrm{n}=6) . *{ }^{* *}$, and $* * *$ indicate significant differences at $P<$ $0.05,0.01$, and 0.001 , respectively. Ns indicates nonsignificant differences. When analysis of variance two-way was significant, means of the treatments was separated according to Duncan's multiple range test.

Table 2. Concentration of non-structural carbohydrates total soluble sugars, reducing sugars, starch on leaves, and roots of flooded and non-flooded 'Verna' lemon (VL) trees grafted on 'Sour' orange (SO) rootstock, either without an interstock (VL/SO) or interstocked with 'Valencia' orange (VL/V/SO) or with 'Castellano' orange (VL/C/SO).

\begin{tabular}{|c|c|c|c|c|}
\hline Rootstock & Flooding & $\begin{array}{l}\text { Solubles sugar } \\
(\mu \mathrm{g} \text { gluc/mg dw })\end{array}$ & $\begin{array}{l}\text { Reducing sugars } \\
\text { ( } \mu \text { g gluc/mg dw) }\end{array}$ & $\begin{array}{c}\text { Starch } \\
(\mu \mathrm{g} \text { gluc/mg dw })\end{array}$ \\
\hline & & Leaves & & \\
\hline \multirow[t]{2}{*}{$\mathrm{VL} / \mathrm{SO}$} & Non-flooded & $72.9^{d} \pm 2.2$ & $40.4^{\mathrm{cd}} \pm 2.2$ & $25.2^{\mathrm{c}} \pm 9.2$ \\
\hline & Flooded & $120.0^{\mathrm{a}} \pm 1.4$ & $42.7^{\mathrm{bcd}} \pm 4.0$ & $44.9^{b} \pm 4.7$ \\
\hline \multirow[t]{2}{*}{$\mathrm{VL} / \mathrm{V} / \mathrm{SO}$} & Non-flooded & $92.0^{b c} \pm 4.10$ & $39.3^{\mathrm{cd}} \pm 4.0$ & $3.5^{\mathrm{d}} \pm 0.3$ \\
\hline & Flooded & $80.1^{\mathrm{cd}} \pm 6.8$ & $50.0^{\mathrm{a}} \pm 2.7$ & $58.1^{\mathrm{a}} \pm 1.9$ \\
\hline \multirow{2}{*}{$\mathrm{VL} / \mathrm{C} / \mathrm{SO}$} & Non-flooded & $103.4^{\mathrm{b}} \pm 2.3$ & $35.1^{\mathrm{d}} \pm 2.9$ & $4.6^{\mathrm{d}} \pm 1.2$ \\
\hline & Flooded & $73.7^{\mathrm{d}} \pm 7.5$ & $46.9^{\mathrm{bc}} \pm 0.5$ & $60.6^{\mathrm{a}} \pm 1.1$ \\
\hline Rootstock & & NS & NS & NS \\
\hline Flooding & & NS & ** & $* * *$ \\
\hline \multirow[t]{2}{*}{$\mathrm{R} \times \mathrm{F}$} & & $* * *$ & $*$ & $* * *$ \\
\hline & & Roots & & \\
\hline \multirow[t]{2}{*}{$\mathrm{VL} / \mathrm{SO}$} & Non-flooded & $38.9^{\mathrm{b}} \pm 3.2$ & $11.6^{\mathrm{c}} \pm 1.4$ & $3.5^{\mathrm{b}} \pm 0.7$ \\
\hline & Flooded & $55.0^{\mathrm{a}} \pm 2.7$ & $28.1^{\mathrm{a}} \pm 1.7$ & $0.36^{\mathrm{d}} \pm 0.01$ \\
\hline \multirow[t]{2}{*}{$\mathrm{VL} / \mathrm{V} / \mathrm{SO}$} & Non-flooded & $37.6^{\mathrm{b}} \pm 1.1$ & $15.8^{b} \pm 0.7$ & $10.5^{\mathrm{a}} \pm 0.5$ \\
\hline & Flooded & $13.7^{\mathrm{d}} \pm 4.2$ & $4.4^{\mathrm{d}} \pm 0.3$ & $0.29^{\mathrm{d}} \pm 0.03$ \\
\hline \multirow[t]{2}{*}{$\mathrm{VL} / \mathrm{C} / \mathrm{SO}$} & Non-flooded & $36.0^{b} \pm 2.4$ & $18.1^{b} \pm 1.1$ & $2.2^{\mathrm{c}} \pm 0.3$ \\
\hline & Flooded & $27.8^{\mathrm{c}} \pm 1.0$ & $10.6^{\mathrm{c}} \pm 0.2$ & $0.36^{\mathrm{d}} \pm 0.02$ \\
\hline Rootstock (R) & & $* * *$ & $* * *$ & $* * *$ \\
\hline Flooding $(\mathrm{F})$ & & * & NS & $* * *$ \\
\hline $\mathrm{R} \times \mathrm{F}$ & & $* *$ & $* * *$ & $* * *$ \\
\hline
\end{tabular}

Values are the mean of six samples $( \pm \mathrm{SE})$.

$*, * *$, and $* * *$ indicate significant differences at $P<0.05,0.01$, and 0.001 , respectively. NS $=$ nonsignificant differences. Means followed by different letters are significantly different $(P<0.05)$ according to Duncan's multiple range tests.

$\mathrm{dw}=$ dry weight.

and QAC in many plants represents a general response to abiotic stresses (Yin et al., 2005). In our experiment, leaf proline concentration was increased by flooding but only in those trees in which the greatest leaf dehydration occurred (in VL/V/SO). This supports the idea that citrus leaf dehydration can increase the synthesis of proline (Pérez-Pérez et al., 2007). However, because there was no correlation between leaf proline concentration and $\Psi_{\pi}^{100}$, the accumulation of proline was not sufficient to contribute to any osmotic adjustment. The QACs were also increased by flooding in all trees, but this increase was also not related osmotic adjustment. In citrus, the main QAC is the proline betaine (Nolte et al., 1997), which also can be increased when citrus trees suffer drought stress (PérezPérez et al., 2007). Parallel to the increase in leaf proline and QAC, a decrease in the root proline and QAC concentrations occurred. This could have been the result of either the degradation of organic solutes during flooding or that these compounds were transported from roots to shoots. The combined total content of proline and QAC in the shoots and roots increased less than the decrease in the roots supporting the idea that the decrease of root organic solute concentration could have been the result of their degradation during flooding.

Effect of flooding on carbohydrate. Nonstructural carbohydrate concentrations were affected by flooding differently in interstocked and non-interstocked trees. Flooding increased the concentration of carbohydrate in leaves by increasing the soluble sugar in $\mathrm{VL} / \mathrm{SO}$ and by increasing the starch in $\mathrm{VL} / \mathrm{V} /$ $\mathrm{SO}$ and $\mathrm{VL} / \mathrm{C} / \mathrm{SO}$. In roots, the carbohydrate concentration was decreased in flooded interstocked trees. A switch from aerobic to anaerobic metabolism requires a larger sugar pool to support fermentative metabolism (Medina et al., 2009). However, in VL/SO, there was a decrease in the starch but the soluble sugar was increased. This could indicate that detrimental effects of flooding in carbohydrate metabolism occurred earlier in interstocked trees than in non-interstocked trees in which the soluble sugar degradation has not started yet to support fermentative metabolism.

In summary, although interstocks in citrus trees can improve the salt tolerance, 'Verna' lemon trees interstocked with orange varieties did not improve the flooding tolerance. When 'Valencia' orange was used as the interstock, the flooding tolerance was drastically reduced. Thus, the use of interstocked trees should be viewed with caution in areas that are subject to flooding. Nutritional responses to flooding occurred in roots as $\mathrm{Fe}, \mathrm{Cu}, \mathrm{Mn}$, and $\mathrm{Ca}$ increased, whereas N P, K decreased. The detrimental effect of flooding in 'Verna' lemon trees was the result of leaf dehydration, which caused a decrease in $\mathrm{A}_{\mathrm{CO} 2}$ through nonstomatal factors. The most severe leaf dehydration occurred in $\mathrm{VL} / \mathrm{V} / \mathrm{SO}$ trees in which leaf chlorophyll fluorescence showed damage to the photosynthetic machinery. Lowered $\mathrm{A}_{\mathrm{CO} 2}$ did not decrease the leaf carbohydrate concentration. Flooding decreased root starch in all trees but more so in $\mathrm{VL} / \mathrm{V} / \mathrm{SO}$ trees. Sugars were decreased by flooding in roots of interstocked trees but were increased by flooding in VL/SO roots suggesting that the translocation of carbohydrates from shoots to roots under flooded condition was impaired in interstocked trees. 
Table 3. Concentration of $\mathrm{Ca}^{2+}, \mathrm{K}^{+}, \mathrm{Mg}^{2+}, \mathrm{P}$, and $\mathrm{N}$ in the leaves and roots of flooded and non-flooded 'Verna' lemon (VL) trees grafted on 'Sour' orange (SO) rootstock, either without an interstock (VL/ $\mathrm{SO}$ ) or interstocked with 'Valencia' orange (VL/V/SO) or with 'Castellano' orange (VL/C/SO).

\begin{tabular}{|c|c|c|c|c|c|c|}
\hline Rootstock & Flooding & $\mathrm{Ca}(\%)$ & $\mathrm{K}(\%)$ & $\operatorname{Mg}(\%)$ & $\mathrm{P}(\%)$ & $\mathrm{N}(\%)$ \\
\hline & & & Leaves & & & \\
\hline \multirow{2}{*}{$\mathrm{VL} / \mathrm{SO}$} & Non-flooded & $2.5 \pm 0.2$ & $1.8 \pm 0.1$ & $0.39 \pm 0.03$ & $0.10 \pm 0.01$ & $2.5 \pm 0.1$ \\
\hline & Flooded & $2.1 \pm 0.2$ & $1.9 \pm 0.2$ & $0.34 \pm 0.04$ & $0.12 \pm 0.01$ & $2.4 \pm 0.2$ \\
\hline \multirow[t]{2}{*}{$\mathrm{VL} / \mathrm{V} / \mathrm{SO}$} & Non-flooded & $2.0 \pm 0.1$ & $1.7 \pm 0.1$ & $0.38 \pm 0.02$ & $0.11 \pm 0.01$ & $2.4 \pm 0.1$ \\
\hline & Flooded & $2.3 \pm 0.1$ & $1.6 \pm 0.1$ & $0.40 \pm 0.03$ & $0.12 \pm 0.01$ & $2.4 \pm 0.1$ \\
\hline \multirow[t]{2}{*}{$\mathrm{VL} / \mathrm{C} / \mathrm{SO}$} & Non-flooded & $2.3 \pm 0.2$ & $1.8 \pm 0.1$ & $0.37 \pm 0.02$ & $0.12 \pm 0.06$ & $2.5 \pm 0.1$ \\
\hline & Flooded & $2.4 \pm 0.1$ & $1.8 \pm 0.1$ & $0.40 \pm 0.04$ & $0.11 \pm 0.00$ & $2.5 \pm 0.1$ \\
\hline \multicolumn{2}{|l|}{ Rootstock (R) } & NS & NS & NS & NS & NS \\
\hline \multicolumn{2}{|l|}{ Flooding (F) } & NS & NS & NS & NS & NS \\
\hline \multicolumn{2}{|l|}{$\mathrm{R} \times \mathrm{F}$} & NS & NS & NS & NS & NS \\
\hline \multirow{3}{*}{$\mathrm{VL} / \mathrm{SO}$} & & & Roots & & & \\
\hline & Non-flooded & $4.2 \pm 0.8$ & $1.8 \pm 0.2$ & $0.36 \pm 0.04$ & $0.13 \pm 0.02^{\mathrm{b}}$ & $2.1 \pm 0.2$ \\
\hline & Flooded & $7.0 \pm 0.9$ & $0.78 \pm 0.13$ & $0.46 \pm 0.05$ & $0.09 \pm 0.01^{\mathrm{bc}}$ & $1.3 \pm 0.1$ \\
\hline \multirow[t]{2}{*}{$\mathrm{VL} / \mathrm{V} / \mathrm{SO}$} & Non-flooded & $3.1 \pm 0.4$ & $1.4 \pm 0.2$ & $0.34 \pm 0.03$ & $0.17 \pm 0.02^{\mathrm{a}}$ & $2.3 \pm 0.1$ \\
\hline & Flooded & $5.6 \pm 0.7$ & $0.48 \pm 0.14$ & $0.32 \pm 0.04$ & $0.06 \pm 0.01^{\mathrm{c}}$ & $1.2 \pm 0.1$ \\
\hline \multirow[t]{2}{*}{$\mathrm{VL} / \mathrm{C} / \mathrm{SO}$} & Non-flooded & $3.2 \pm 0.2$ & $1.3 \pm 0.3$ & $0.35 \pm 0.02$ & $0.13 \pm 0.01^{\mathrm{b}}$ & $2.5 \pm 0.1$ \\
\hline & Flooded & $6.7 \pm 0.3$ & $0.86 \pm 0.09$ & $0.47 \pm 0.03$ & $0.13 \pm 0.02^{\mathrm{b}}$ & $1.5 \pm 0.1$ \\
\hline Rootstock & & NS & NS & NS & NS & NS \\
\hline Flooding & & $* * *$ & $* * *$ & * & $* * *$ & $* * *$ \\
\hline $\mathrm{R} \times \mathrm{F}$ & & NS & NS & NS & $* *$ & NS \\
\hline
\end{tabular}

Values are the mean of six samples $( \pm \mathrm{SE})$.

$*$,**, and *** indicate significant differences at $P<0.05,0.01$, and 0.001 , respectively. NS $=$ nonsignificant differences. Means followed by different letters are significantly different $(P<0.05)$ according to Duncan's multiple range tests.

$\mathrm{Ca}=$ calcium $; \mathrm{K}=$ potassium $; \mathrm{Mg}=$ magnesium; $\mathrm{P}=$ phosphorus; $\mathrm{N}=$ nitrogen.

Table 4. Concentration of $\mathrm{Cu}, \mathrm{Fe}, \mathrm{Mn}$, and $\mathrm{Zn}$ in leaves and roots in the leaves and roots of flooded and nonflooded 'Verna' lemon (VL) trees grafted on 'Sour' orange (SO) rootstock, either without an interstock (VL/SO) or interstocked with 'Valencia' orange (VL/V/SO) or with 'Castellano' orange (VL/C/SO).

\begin{tabular}{|c|c|c|c|c|c|}
\hline Rootstock & Flooding & $\mathrm{Cu}\left(\mathrm{mg} \cdot \mathrm{kg}^{-1}\right)$ & $\mathrm{Fe}\left(\mathrm{mg} \cdot \mathrm{kg}^{-1}\right)$ & $\mathrm{Mn}\left(\mathrm{mg} \cdot \mathrm{kg}^{-1}\right)$ & $\mathrm{Zn}\left(\mathrm{mg} \cdot \mathrm{kg}^{-1}\right)$ \\
\hline & & & ves & & \\
\hline \multirow[t]{2}{*}{$\mathrm{VL} / \mathrm{SO}$} & Non-flooded & $5.2 \pm 0.9$ & $50.2 \pm 7.7$ & $13.5 \pm 1.7$ & $11.7 \pm 1.7$ \\
\hline & Flooded & $5.6 \pm 0.7$ & $57.7 \pm 5.8$ & $10.7 \pm 2.0$ & $11.2 \pm 1.1$ \\
\hline \multirow[t]{2}{*}{ VL/V/SO } & Non-flooded & $4.5 \pm 0.3$ & $89.1 \pm 22.2$ & $10.7 \pm 1.3$ & $10.3 \pm 0.4$ \\
\hline & Flooded & $5.9 \pm 0.5$ & $89.4 \pm 29.4$ & $10.4 \pm 2.5$ & $9.1 \pm 0.3$ \\
\hline \multirow[t]{2}{*}{$\mathrm{VL} / \mathrm{C} / \mathrm{SO}$} & Non-flooded & $5.9 \pm 0.4$ & $99.5 \pm 22.1$ & $9.4 \pm 0.3$ & $11.9 \pm 1.1$ \\
\hline & Flooded & $7.2 \pm 0.6$ & $47.8 \pm 5.0$ & $10.7 \pm 0.4$ & $10.3 \pm 1.2$ \\
\hline \multirow{3}{*}{$\begin{array}{l}\text { Rootstock (R) } \\
\text { Flooding }(\mathrm{F}) \\
\mathrm{R} \times \mathrm{F}\end{array}$} & & NS & NS & NS & NS \\
\hline & & NS & NS & NS & NS \\
\hline & & NS & NS & NS & NS \\
\hline \multicolumn{6}{|c|}{ Roots } \\
\hline \multirow[t]{2}{*}{$\mathrm{VL} / \mathrm{SO}$} & Non-flooded & $20.1 \pm 4.2$ & $2790 \pm 408$ & $92 \pm 15$ & $17.8 \pm 1.3$ \\
\hline & Flooded & $41.65 \pm 5.4$ & $5825 \pm 694$ & $197 \pm 38$ & $28.4 \pm 9.6$ \\
\hline \multirow[t]{2}{*}{$\mathrm{VL} / \mathrm{V} / \mathrm{SO}$} & Non-flooded & $19.9 \pm 1.4$ & $2044 \pm 34$ & $64 \pm 8$ & $18.2 \pm 0.9$ \\
\hline & Flooded & $25.0 \pm 1.5$ & $4608 \pm 675$ & $162 \pm 8$ & $16.4 \pm 2.0$ \\
\hline \multirow[t]{2}{*}{$\mathrm{VL} / \mathrm{C} / \mathrm{SO}$} & Non-flooded & $14.3 \pm 1.4$ & $1751 \pm 178$ & $47 \pm 4$ & $16.0 \pm 0.8$ \\
\hline & Flooded & $32.9 \pm 2.4$ & $5874 \pm 384$ & $219 \pm 15$ & $20.5 \pm 1.9$ \\
\hline Rootstock & & $*$ & NS & NS & NS \\
\hline Flooding & & $* * *$ & $* * *$ & $* * *$ & NS \\
\hline $\mathrm{R} \times \mathrm{F}$ & & NS & NS & NS & NS \\
\hline
\end{tabular}

Values are the mean of six samples $( \pm \mathrm{SE})$.

$*$,**, and *** indicate significant differences at $P<0.05,0.01$, and 0.001 , respectively. NS $=$ nonsignificant differences.

$\mathrm{Cu}=$ copper; $\mathrm{Fe}=$ iron; $\mathrm{Mn}=$ manganese $; \mathrm{Zn}=$ zinc.

\section{Literature Cited}

Agusti, M., V. Almela, M. Juan, C. Mesejo, and A. Martínez-Fuentes. 2003. Rootstock influence on the incidence of rind breakdown in 'Navelate' sweet orange. J. Hort. Sci. Biotechnol. 78:554 558.

Arbona, V., Z. Hossain, M.F. López-Climent, R.M. Pérez-Clemente, and A. Gómez-Cadenas. 2008. Antioxidant enzymatic activity is linked
Dixon, M.H., S.A. Hill, M.B. Jackson, R.G. Ratcliffe, and L.J. Sweetlove. 2006. Physiological and metabolic adaptations of Potamogeton pectinatus L. tubers support rapid elongation of stem tissue in the absence of oxygen. Plant Cell Physiol. 47:128-140.

Domingo, R., A. Pérez-Pastor, and M.C. RuízSánchez. 2002. Physiological responses of apricot plants grafted on two different rootstocks to flooding conditions. J. Plant Physiol. 159:725732.

Else, M.A., A.E. Tiekstra, S.J. Croker, W.J. Davies, and M.B. Jackson. 1996. Stomatal closure in flooded tomato plants involves abscisic acid and a chemically unidentified anti-transpirant in xylem sap. Plant Physiol. 112:239-247.

Farquhar, G.D. and T.D. Sharkey. 1982. Stomatal conductance and photosynthesis. Annu. Rev. Plant Physiol. 33:317-345.

Fernández, M.D., A. Pieters, and C. Donoso. 1999. Seasonal changes in photosynthesis of trees in the flooded forest of the Mapire River. Tree Physiol. 19:79-85.

Flexas, J., J. Bota, F. Loreto, G. Cornic, and T.D. Sharkey. 2004. Diffusive and metabolic limitations to photosynthesis under drought and salinity in C-3 plants. Plant Biol. 6:269-279.

García-Sánchez, F. and J.P. Syvertsen. 2009. Substrate type and salinity affect growth allocation, tissue ion concentrations, and physiological responses of Carrizo citrange seedlings. HortScience 44:432-437.

García-Sánchez, F., J.P. Syvertsen, V. Gimeno, P. Botía, and J.G. Pérez-Pérez. 2007. Responses to flooding and drought stress by two citrus rootstock seedlings with different water-use efficiency. Physiol. Plant. 130:532-542.

Gil-Izquierdo, A., M.T. Riquelme, I. Porras, and F. Ferreres. 2004. Effect of the rootstock and interstock grafted in lemon tree (Citrus limon L. Burm.) on the flavonoid content of lemon juice. J. Agr. Food Chem. 52:324-331.

Gilliham, M., M. Dayod, B.J. Hocking, B. Xu, S.J. Conn, B.N. Kaiser, R.A. Leigh, and S.D. Tyerman. 2011. Calcium delivery and storage in plant leaves: Exploring the link with water flow. J. Expt. Bot. 62:2233-2250.

Gimeno, V., J.P. Syvertsen, M. Nieves, I. Simón, V. Martínez, and F. García-Sánchez. 2009a. Additional nitrogen fertilization affects salt tolerance of lemon trees on different rootstocks. Sci. Hort. 121:298-305.

Gimeno, V., J.P. Syvertsen, M. Nieves, I. Simón, V. Martínez, and F. García-Sánchez. 2009b. Orange varieties as interstocks increase the salt tolerance of lemon trees. J. Hort. Sci. Biotechnol. 84:625-631.

Glenz, C., R. Schlaepfer, I. Iorgulescu, and F. Kienast. 2006. Flooding tolerance of Central European tree and shrub species. For. Ecol. Mgt. 235:1-13.

Greenway, H. and J. Gibbs. 2003. Mechanisms of anoxia tolerance in plants. II. Energy requirements for maintenance and energy distribution to essential processes. Funct. Plant Biol. 30:9991036.

Grieve, C.M. and S.R. Grattan. 1983. Rapid assay for determination of water-soluble quaternary ammonium-compounds. Plant Soil 70:303-307.

Haissig, B.E. and R.E. Dickson. 1979. Starch measurements in plant tissue using enzymatic hydrolysis. Plant Physiol. 47:151-157.

Hodge, J.E. and B.T. Hofreiter. 1962. Determination of reducing sugars and carbohydrates, p. 380-394. In: Whistler, R.L., and M.L. Wolfram (eds.). Methods in carbohydrate chemistry, vol. 1. Academic Press, New York, NY. 
Horchani, F., R. Hajri, H. Khayati, and S. AschiSmiti. 2010. Physiological responses of tomato plants to the combined effect of root hypoxia and $\mathrm{NaCl}$ salinity. J. Phytol. 2:36-46.

Hossain, Z., M.F. López-Climent, V. Arbona, R.M. Pérez-Clemente, and A. Gómez-Cadenas. 2009. Modulation of the antioxidant system in citrus under waterlogging and subsequent drainage. J. Plant Physiol. 166:1391-1404.

Islam, M.A., M.E. MacDonald, and J.J. Zwiazek. 2003. Responses of black spruce (Picea mariana) and tamarack (Larix laricina) to flooding and ethylene. Tree Physiol. 23:545-552.

Kijne, J.W. 2006. Abiotic stress and water scarcity: Identifying and resolving conflicts from plant level to global level. Field Crops Res. 97:3-18.

Kozlowski, T.T. 1997. Responses of woody plants to flooding and salinity. Tree Physiol. Monograph No. 1. Heron Publishing, Victoria, Canada.

Li, M., D. Yang, and W. Li. 2007. Leaf gas exchange characteristics and chlorophyll fluorescence of three wetland plants in response to long-term soil flooding. Photosynthetica 45: 222-228.

Li, S., S.R. Pesezki, S. Goodwin, and F.D.J. Shields. 2004. Physiological responses of black willow (Salix nigra) cuttings to a range of soil moisture regimes. Photosynthetica 42:585590.

Little, T.M. and J.J. Hills. 1978. Agricultural experimentation: Design and analysis. John Wiley, New York, NY.

Magneschi, L. and P. Perata. 2009. Rice germination and seedling growth in the absence of oxygen. Ann. Bot. (Lond.) 103:181-196.

Maxwell, K. and G.N. Johnson. 2000. Chlorophyll fluorescence-A practical guide. J. Expt. Bot. 51:659-668

Medina, C.L., M.C. Sánches, M.L.S. Tucci, C.A.F. Sousa, G.R.F. Cuzzuol, and C.A. Joly. 2009. Erythrina speciosa (LeguminosaePapilionoideae) under soil water saturation: Morphophysiological and growth responses. Ann. Bot. (Lond.) 104:671-680.

Morgan, J.M. 1984. Osmoregulation and water stress in higher plants. Annu. Rev. Plant Physiol. 35:299-319.
Nabben, R.H.M., C.W.P.M. Blom, and L.A.C.J. Voesenek. 1999. Resistance to complete submergence in Rumex species with different life histories: The influence of plant size and light. New Phytol. 144:313-321.

Naumann, J.C., D.R. Young, and J.E. Anderson. 2008. Leaf chlorophyll fluorescence, reflectance, and physiological response to freshwater and saltwater flooding in the evergreen shrub, Myrica cerifera. Environ. Exp. Bot. 63:402409.

Nelson, N. 1944. A photometric adaptation of the Somogyi method for the determination of glucose. J. Biol. Chem. 153:380-395.

Nobel, P.S. 1991. Physicochemical and environmental plant physiology. Academic Press, Inc. San Diego, CA.

Nolte, K.D., A.D. Hanson, and D.A. Gage. 1997. Proline accumulation and methylation to proline betaine in citrus: Implications for genetic engineering of stress resistance. J. Amer. Soc. Hort. Sci. 122:8-13.

Ortuño, M.F., J.J. Alarcon, E. Nicolas, and A. Torrecillas. 2007. Water status indicators of lemon trees in response to flooding and recovery. Biol. Plant. 2:292-296.

Pereira, W.E., D.L. de Siqueira, C.A. Martínez, and M. Puiatti. 2000. Gas exchange and chlorophyll fluorescence in four citrus rootstocks under aluminum stress. J. Plant Physiol. 157:513520.

Pérez-Pérez, J.G., J.P. Syvertsen, P. Botía, and F. García-Sánchez. 2007. Leaf water relations and net gas exchange responses of salinized Carrizo citrange seedlings during drought stress and recovery. Ann. Bot. (Lond.) 100:335-345.

Rengel, Z. 1992. Modeling magnesium uptake from an acid soil. IV. Depletion of magnesium, calcium, and potassium from soluble and exchangeable phase. Commun. Soil Sci. Plant Anal. 23:165-174.

Rodríguez-Gamir, J., G. Ancillo, M.C. GonzálezMas, E. Primo-Millo, D.J. Iglesias, and M.A Forner-Giner. 2011. Root signalling and modulation of stomatal closure in flooded citrus seedlings. Plant Physiol. Biochem. 49:636-645.

Ruíz-Sánchez, M.C., R. Domingo, D. Morales, and A. Torrecillas. 1996. Water relations of
Fino lemon plants on two rootstocks under flooded conditions. Plant Sci. 120:119-125.

Saleh, B., T. Allario, D. Dambier, P. Ollitrault, and R. Morillon. 2008. Tetraploid citrus rootstocks are more tolerant to salt stress than diploid. C. R. Biol. 331:703-710.

Somogyi, M. 1952. Notes and sugar determination. J. Biol. Chem. 195:19-23.

Striker, G.G., P. Insausti, and A.A. Grimoldi. 2007. Effects of flooding at early summer on plant water relations of Lotus tenuis. Lotus Newsletter $37: 1-7$.

Syvertsen, J.P. 1984. Light acclimation in citrus leaves. II. $\mathrm{CO}_{2}$ assimilation and light, water, and nitrogen use efficiency. J. Amer. Soc. Hort. Sci. 109:812-817.

Syvertsen, J.P., R.M. Zablotowicz, and M.L. Smith. 1983. Soil temperature and flooding effects on two species of citrus. I. Plant growth and hydraulic conductivity. Plant Soil 72:3-12.

Turner, N.C. 1988. Measurement of plant water status by the pressure chamber technique. Irrig. Sci. 9:289-308.

Unger, I.M., R.-M. Muzika, and P.P. Motavalli. 2010. The effect of flooding and residue incorporation on soil chemistry, germination and seedling growth. Environ. Exp. Bot. 69:113-120.

Vu, J.C.V. and G. Yelenosky. 1991. Photosynthetic responses of citrus trees to soil flooding. Physiol. Plant. 81:7-14.

Waldren, S., J.R. Etherington, and M.S. Davies. 1987. Comparative studies of plant growth and distribution in relation to waterlogging. XIV. Iron, manganese, calcium and phosphorus concentrations in leaves and roots of Geum rivale L. and G. urbanum L. grown in waterlogged soil. New Phytol. 106:689-696.

Yelenoski, G., J.C.V. Vu, and H.K. Wutscher. 1995. Influence of paclobutrazol in the soil on growth, nutrient elements in the leaves, and flood/freeze tolerance of citrus rootstock seedlings. J. Plant Growth Regul. 14:129-134.

Yin, C.Y., Y.H. Peng, R.G. Zang, Y.P. Zhu, and C.Y. Li. 2005. Adaptive responses of Populus kangdingensis to drought stress. Physiol. Plant. 123:445-451.

Zubay, G. 1993. Biochemistry. 3rd Ed. Wm. C. Brown Publishers, Dubuque, IA. 